[Vol. 129:182

\title{
COMMENTS
}

\section{PRESUMED DAMAGES FOR FOURTH AMENDMENT VIOLATIONS}

Over the past decade, private damage actions against government officials have assumed increasing importance as a mechanism for the vindication of constitutional rights. The Supreme Court's landmark decision in Bivens v. Six Unknown Named Agents of the Federal Bureau of Narcotics ${ }^{1}$ opened the federal courts to damage suits by individuals whose constitutional rights have been violated by federal officials. Similar suits ${ }^{2}$ against state officials in federal court, long allowed under 42 U.S.C. $\$ 1983^{3}$ have enjoyed a burst of popularity. ${ }^{4}$ The Supreme Court recently extended the reach of section 1983 to suits directly against local governments, ${ }^{5}$ and

1403 U.S. 388 ( 1971 ). The Court recognized a direct cause of action against federal officials for a violation of the fourth amendment, rejecting the government's argument that plaintiffs must sue under a state tort cause of action. A direct action against federal officials has also been implied for other constitutional violations. See, e.g., Davis v. Passman, 442 U.S. 228 (1979) (fifth amendment); Paton v. La Prade, 524 F.2d 862 (3d Cir. 1975) (first amendment); Berlin Dem. Club v. Rumsfeld, 410 F. Supp. 144 (D.D.C. 1976) (sixth amendment); Patmore v. Carlson, 392 F. Supp. 737 (E.D. Ill. 1975) (eighth amendment).

$2 \mathrm{~A}$ line of lower federal court decisions has expressly characterized the Bivens action as the federal counterpart to $\$ 1983$. See Butz v. Economou, 438 U.S. 478, 500 (1978). Thus, this Comment draws few substantive distinctions between $\$ 1983$ and Bivens actions. But see notes 51 \& 104 infra.

3 The statute provides that:

Every person who, under color of any statute, ordinance, regulation, custom, or usage, of any State or Territory, or the District of Columbia, subjects, or causes to be subjected, any citizen of the United States or other person within the jurisdiction thereof to the deprivation of any rights, privileges, or immunities secured by the Constitution and laws, shall be liable to the party injured in an action at law, suit in equity, or other proper proceeding for redress. For the purposes of this section, any Act of Congress applicable exclusively to the District of Columbia shall be considered to be a statute of the District of Columbia.

42 U.S.C.A. $\$ 1983$ (Supp. 1980). This section was enacted as $\S 1$ of the Civil Rights Act of 1871 , 17 Stat. 13.

Original jurisdiction over $\$ 1983$ claims is vested in the lower federal courts by 28 U.S.C. $\$ 1343$ (3) (1976).

4 See Love, Damages: A Remedy for the Violation of Constitutional Rights, 67 CALrF. L. REv. 1242 (1979); Newman, Suing the Lawbreakers: Proposals to Strengthen the Section 1983 Damage Remedy for Law Enforcers' Misconduct, 87 YAXE L.J. 447, 451-53 (1978).

5 Monell v. Department of Social Servs., 436 U.S. 658 (1978). Further, the proposed Civil Rights Improvements Act would significantly expand the potential liability of municipalities by allowing, inter alia, in some circumstances, recovery of damages against a city, even if an official acted contrary to city policy. See S. 
legislation that would add the United States itself to the list of potential defendants has been proposed in recent sessions of Congress. $^{B}$ For victims of official lawlessness and for society, however, access to the appropriate defendant is of little use and slight value unless success on the merits of the claim will ensure a damage recovery that adequately compensates for the loss the governmental body or official has inflicted and deters the governmental body or official from future violations. Workable rules defining the elements of compensable loss and the procedures for assigning that loss a dollar value in a particular case are crucial in order to allow the courts to promise vindication of constitutional rights to all citizens.

The doctrine of presumed damages ${ }^{7}$ has been suggested as a means of bringing more consistency and equity to awards of damages for constitutional torts that do not cause substantial measurable pecuniary loss. ${ }^{8}$ This Comment will explore the presumed damages concept and its potential utility in the fourth amendment context. After defining certain tort law damage concepts as background to the ensuing discussion, part I will identify certain problems in the assessment and review of constitutional tort damage awards and compare alternative approaches to these problems with the solution offered by the doctrine of presumed damages. Part II will then focus specifically on the presumed damage doctrine in the area of fourth amendment violations. In the recent case of Halperin $v$. Kissinger, ${ }^{9}$ the Court of Appeals for the District of Columbia refused to apply the doctrine of presumed damages in the context of wiretapping concededly violative of the fourth amendment. ${ }^{10}$ Al-

1983, 96th Cong., 1st Sess., 125 Conc. REc. 515, 994 (daily ed. Nov. 6, 1979); Comment, The Collateral-Estoppel Effect to be Given State-Court Judgments in Federal Section 1983 Damage Suits, 128 U. PA. L. Rev. 1471, 1487 n.77 (1980).

${ }^{6}$ See H.R. 2659, 96th Cong., 1st Sess., 125 Cong. Rec. H1107 (daily ed. March 6, 1979); S. 695, 96th Cong., Ist Sess., 125 Cong. REc. S2919 (daily ed. March 15, 1979). These proposed amendments to the Federal Tort Claims Act, (codified at 28 U.S.C. $\$ \$ 2671-2680$ (1976)), would make the United States the sole defendant in suits for torts committed by federal employees within the scope of their employment.

7 The doctrine of presumed damages provides that substantial injury may be presumed to flow from certain tortious acts when they invade interests that are not capable of precise physical or monetary measurement. See text following note 54 infra.

8 See Love, supra note 4, at 1282; Newman, supra note 4, at 465; Note, Damage Awards for Constitutional Torts: A Reconsideration After Carey v. Piphus, 93 Harv. L. Rev. 966 (1980) [hereinafter cited as Harvard Note].

o 606 F.2d 1192 (D.C. Cir. 1979), cert. granted, 100 S. Ct. 2915 (1980) (No. 79-880).

10 Numerous other issues dealt with in Halperin, including interpretation and application of Title III of the Omnibus Crime Control and Safe Streets Act of 
though the Supreme Court, in Carey v. Piphus, ${ }^{11}$ rejected a presumption of substantial damage in the procedural due process area, the Court recognized that different rules may be appropriate to remedy different constitutional wrongs. ${ }^{12}$ This Comment takes the position that the Halperin court should have held that the plaintiffs in that case were entitled to a presumption of substantial injury, in light of important differences between fourth amendment and procedural due process rights.

\section{Problems in Assessing Damages for Deprivations of Constitutional Rights}

The task of fashioning the federal law of constitutional tort damages has been left largely to the lower federal courts, pursuant to the Supreme Court's command to adapt the common law of remedies to the needs of constitutional enforcement. ${ }^{13}$ Apart from Carey v. Piphus, in which the holding was expressly limited to the

1968, 18 U.S.C. $\$ \$ 2510-2520$ (1976 \& Supp. III 1979) [hereinafter cited as Title III], and doctrines of official immunity, are outside the scope of this Comment.

11435 U.S. 247 (1978). In Piphus, two students alleged that they were suspended from public elementary and secondary schools without procedural due process and sued school officials under $\$ 1983$ for violation of their fourteenth amendment rights. The Court held that, in the absence of proof of actual injury, only nominal damages should be awarded for the denial of procedural due process. See notes 73-88 infra \& accompanying text.

12435 U.S. at $264-65$.

13 In some cases, the interests protected by a particular branch of the common law of torts may parallel closely the interests protected by a particular constitutional right. In such cases, it may be appropriate to apply the tort rules of damages directly to the $\$ 1983$ action. . . . In [other] cases, the task will be the more difficult one of adapting common-law rules of damages to provide fair compensation for injuries caused by the deprivation of a constitutional right.

Carey v. Piphus, 435 U.S. 247, 258 (1978).

Piphus is, in reality, only the latest in a line of Supreme Court opinions issuing this directive to the lower federal courts. See Bivens v. Six Unknown Named Agents of the Fed. Bureau of Narcotics, 403 U.S. 388, 407-09 (1971) (Harlan, J., concurring) (judges should adapt their experience with traditional private tort actions to accord "meaningful compensation" for invasion of fourth amendment rights); Adickes v. S. H. Kress \& Co., 398 U.S. 144, 231-32 (1970) (Brennan, J., concurring in part and dissenting in part) (in a case in which denial of equal protection on the basis of race is the theory of recovery in a $\$ 1983$ action, "relief should not depend on the vagaries of the general common law but should be governed by uniform and effective federal standards"); Sullivan v, Little Hunting Park, Inc., 396 U.S. 229, 240 (1969) (damages action for racial discrimination in housing) ("[B]oth federal and state rules on damages may be utilized, whichever better serves the policies expressed in the federal statutes."); Monroe v. Pape, 365 U.S. 167, 196 (1961) (Harlan, J., concurring) ( $\$ 1983$ action for damages from unlawful search and seizure) ("[A] deprivation of a constitutional right is signifcantly different from and more serious than a violation of a state right and therefore deserves a different remedy even though the same act may constitute both a state tort and the deprivation of a constitutional right."), overruled in part on other grounds, Monell v. Department of Social Servs., 436 U.S. 658 (1978). 
procedural due process area, the Court has given little guidance on the rules applicable to specific constitutional violations. ${ }^{14}$ The following is a brief summary of the common law damages concepts that provide the basis for modern constitutional damages law.

\section{A. Common Law Damages Framework}

The law of torts differentiates among three classes of damages: nominal, punitive, and compensatory. ${ }^{15}$

Nominal damages consist of a trifling sum ${ }^{16}$ that serves only as a symbolic declaration that the defendant has invaded a legally protected interest of the plaintiff. ${ }^{17}$ They are awarded in lieu of compensatory damages in certain cases in which the plaintiff succeeds on the merits of his claim but fails to establish his entitlement to a substantial compensatory award..$^{18}$

Punitive damages may be awarded only in addition to either nominal or compensatory damages, and only when the defendant's conduct has been egregious. ${ }^{19}$ Their purpose is to punish those defendants who are not only "at fault" in the tort law sense, but morally reprehensible in some high degree as well. ${ }^{20}$ In addition, they are intended to serve as a deterrent to repetition of the objectionable act. ${ }^{21}$ The American rule, unlike the English standard, requires the jury to label separately the "punitive" portion of its damage award. ${ }^{22}$

Unlike nominal and punitive damages, compensatory awards focus on the harm suffered by the plaintiff and attempt to "undo"

14 See note 13 supra. Lower courts have differed since Piphus on the issue whether to apply Piphus's actual injury requirement or some other measure in cases of constitutional violations. See Harvard Note, supra note 8, at 972-73, notes 146 \& 147 infra \& accompanying text.

16 D. Dobbs, HandBook on the Law of REMEdEs $\$ 3.1$ (1973); RestateMENT (SECOND) OF TORTS $\$ \$ 01-909$ (1977); Love, supra note 4, at 1244-47.

16 The standard amount of nominal damages is one dollar. See D. DobBs, supra note 15, at $\$ 3.8$. But see, e.g., United States ex rel. Motley v. Rundle, 340 F. Supp. 807 (E.D. Pa. 1972) (nominal damage award of $\$ 1000$ ).

17 D. DoBss, supra note 15 , at $\$ 3.8$.

$18 \mathrm{Id}$. Trespass to land cases are an example; the plaintiff has a right to exclusive possession of his land, and though the defendant's trespass causes no compensable economic harm, the plaintiff is entitled to vindicate his right by the recovery of nominal damages. Other actions in which nominal damages are recoverable include battery, assault, false imprisonment, defamation, and malicious prosecution. See id.; Love, supra note 4, at 1246.

19 D. Dosss, supra note 15, at $\S 3.9$. See Love, supra note 4 , at 1279-81.

20 D. DosBs, supra note 15 , at $\$ 3.9$; Love, supra note 4 , at 1278-81.

21 The amount of a punitive award is linked to the defendant's ability to pay. D. DosBs, supra note 15, at §3.9. Apparently, the idea is to set the award at a level that will "pinch" the defendant's pocketbook as well as his conscience.

22 C. MCCormacx, HaNDBOOK ON THE LAW OF DaMages $\$ 78$, at 278-79 (1835). 
the effects of the tortious act. ${ }^{23}$ At the same time, by shifting the economic burden of the tort from the plaintiff to the defendant, compensatory damages serve a deterrent function. ${ }^{24}$ The types of harm recognized as compensable include special damages (pecuniary loss unique to the particular plaintiff, such as medical bills and lost wages), general damages of a pecuniary sort (such as projected loss of income due to impairment of earning capacity), and general damages of a nonpecuniary, or "intangible," sort (such as mental and physical pain and suffering). ${ }^{25}$ The plaintiff bears the burden of proving the fact, proximate causation, and amount of each of these types of damages, ${ }^{26}$ except where his cause of action is based on invasion of certain "dignitary" interests, ${ }^{27}$ such as privacy 28 and voting rights. ${ }^{29}$ It is in these cases that the doctrine of presumed damages played a role at common law. That doctrine provides that substantial injury may be presumed to flow from certain tortious acts, even though the plaintiff has presented no proof of actual loss, when the torts invade interests that are intangible, rather than physical or economic.30 As Professor Dobbs explains, "the wrong is said to be damage in and of itself." 31

\section{B. Compensating for Deprivation of Intangible Constitutional Rights: Alternatives to the Presumed Damages Concept}

Many constitutionally protected rights are intangible in nature: as highly as society values them, one cannot hope to "prove" their value as one would prove the economic value of a tortiously destroyed eye, breadwinner, or prize cow. Federal courts have dealt

23 D. DoBBs, supra note 15 , at $\$ 3.1$.

24 See generally G. Calabresi, The Costs of Accidents chs. 5 \& 6 (1970); R. Posner, AN Economic ANalysis of tre LAW $\$ 4.9$ (1972); Coase, The Problem of Social Cost, 3 J.L. \& Econ. I (1960).

25 See H. McGregor, Damages 16-20 (13th ed. 1972); Love, supta note 4, at $1245 \mathrm{n} .16$.

${ }^{26} \mathrm{D}$. DoBss, supra note 15 , at $\$ 3.2$. Obviously, the "amount" of pain and suffering cannot be proved with mathematical precision, unlike the amount of a hospital bill. Essentially, the valuation of intangible general damages must be left to the jury. See H. McGregor, supra note 25, at 19 .

27 Professor Dobbs defines dignitary invasions as "injuries to the personality. This means that, though economic or physical loss may be associated with the injury, the primary or usual concern is not economic at all, but vindication of an intangible right." D. DoBss, supra note 15, at \$7.1, at 509.

28 See id.; Restatement (SECOND) of ToRts $\$ 652(\mathrm{H})(\mathrm{a})$ (1977).

${ }^{29}$ See Wayne v. Venable, 260 F. 64 (8th Cir. 1919) (right to vote "is so valuable that damages are presumed from the wrongful deprivation of it." Id. 66 ); D. DoBBs, supra note 15 , at $\$ 7.3$. See also note 32 infra \& accompanying text; note 120 infra.

$30 \mathrm{D}$. DoBss, supra note 15 , at $\$ 7.3$.

31 Id. 
with this problem in voting rights cases, for example, by allowing recovery of substantial damages without proof of actual loss. ${ }^{32}$ The logic of such a solution is impeccable. One could easily imagine a situation in which an individual's constitutionally guaranteed right to vote in a federal election is abridged by conduct of a government official that is intentional and tortious but that fails to satisfy the stringent "wanton or malicious" standard necessary for an award of punitive damages. ${ }^{33}$ In all likelihood, such a plaintiff will be unable to prove any actual damage consequent to the tortious act. Yet it is a fundamental tenet of our democratic system that the right to vote is valuable in and of itself. ${ }^{34}$ A judicial refusal to presume damages would restrict one deprived of this right to no, or merely nominal, damages. Such an approach would both belittle the right itself and ensure that suits to vindicate it would be the exclusive preserve of the quixotic.

Although the right to recover substantial damages without proof of actual loss has long been recognized by the federal courts in voting rights cases, ${ }^{35}$ other constitutiontal deprivations, such as those involved in first amendment, fourth amnedment, and racial discrimination cases, have not been consistently recognized as compensable in and of themselves. This result may occur in part because, in some cases, a presumption of substantial damages is not crucial to a plaintiff's success, since actual, provable damage frequently will also result from the violation of these particular intangible constitutional rights. ${ }^{36}$ Thus, the ability to demonstrate

32 See Lane v. Wilson, 307 U.S. 268 (1939); Nixon v. Condon, 286 U.S. 73 (1932); Nixon v. Herndon, 273 U.S. 536 (1927); Giles v. Harris, 189 U.S. 475 (1903); Wiley v. Sinkler, 179 U.S. 58 (1900); Wayne v. Venable, 260 F. 64 (8th Cir. 1919).

33 For discussions of the degree of culpability necessary to support punitive awards in constitutional tort cases, see Fisher v. Volz, 496 F.2d 333, 346-48 (3d Cir. 1974) (jury verdict for punitive damages against police officer for unlawful warrantless search sustained as within the discretion of the trier of fact); Basista v. Weir, 340 F.2d 74, 87 (3d Cir. 1965) (jury could properly award punitive damages under federal common law against police officer for assault, wrongful arrest, denial of bail, and denial of counsel, despite lack of proof of actual damages); Halperin v. Kissinger, 434 F. Supp. 1193, 1195 (D.D.C. 1977) (conduct of federal officials who unconstitutionally wiretapped plaintiff's telephone not "wanton, reckless or malicious disregard of plaintiff's rights" justifying imposition of punitive damages), rev'd in part and remanded, 606 F.2d 1192 (D.C. Cir. 1979), cert. granted, $100 \mathrm{~S}$. Ct. 2915 (1980) (No. 79-880).

34 See note 29 supra.

35 See note 32 supra \& accompanying text.

36 For example, first amendment suits brought by employees discharged for exercising their free speech rights typically seek back pay as the most substantial element of damages. See, e.g., Rivera Morales v. Benitez de Rexach, 541 F.2d 882 (1st Cir. 1976) (back pay awarded for politically motivated discharge of public 
and easily quantify lost wages, medical expenses, and the like has provided sufficient incentive for many plaintiffs to bring suit to enforce certain constitutional rights, even if the right itself is ignored as a separate element of compensable damage due to judicial refusal to presume injury.

In many cases, however, pecuniary losses are trivial or nonexistent, and the only substantial "actual" loss ${ }^{37}$ the plaintiff can hope to prove is mental pain and suffering. Consider, for example, a couple subjected to racial discrimination in their search for housing. The only substantial damage that they have suffered is the affront to their constitutional right to be accorded equal treatment in the housing market. Instead of following the approach of federal courts in voting rights cases and recognizing violation of this right as an element of damages compensable in and of itself, some courts have taken the circuitous route by focusing on the plaintiffs' wounded feelings and insisting that recovery can be had only for "proven" emotional distress, humiliation, and the like. ${ }^{38}$

employee); Donovan v. Reinbold, 433 F.2d 738 (9th Cir. 1970) (lost wages an element of damage award for lifeguard fired in retaliation for political speech).

Further, plaintiffs alleging wrongful arrest and imprisonment can often prove special damages such as lost wages, medical expenses, and the costs of defending malicious prosecution. In addition, if these plaintiffs were physically abused, the trier of fact may award a discretionary sum as compensation for physical suffering. See, e.g., Stringer v. Dilger, 313 F.2d 536 (10th Cir. 1963) (bodily injuries as element of damages for trumped-up arrest and physical abuse by police officer); Brooks v. Moss, 242 F. Supp. 531 (W.D.S.C. 1965) (medical expenses, lost wages, and costs of defending false charges as elements of damages for police assault); MaArthur v. Pennington, 253 F. Supp. 420 (E.D. Tenn. 1963) (lost wages and outof-pocket expenses as elements of damages for false arrest of truckers).

Finally, victims of racial discrimination in housing may be awarded expenses incurred in obtaining alternate living quarters. See, e.g., Gore v. Turner, 563 F.2d 159 (5th Cir. 1977) (actual expenses awarded in suit against apartment-complex operator); Jeanty v. McKey \& Pogue, Inc., 496 F.2d 1119 (7th Cir. 1974) (similar expenses awarded against discriminatory realty agency); Allen v. Gifford, 368 F. Supp. 317 (E.D. Va. 1973) (cost of alternate living arrangements and treatment for resulting mental illness of wife compensated in suit based on housing-sale discrimination).

37 "Actual" loss is used in this Comment to refer to loss that is proven in any way, rather than presumed.

38 For example, in Seaton v. Sky Realty Co., 491 F.2d 634 (7th Cir. 1974), a racial housing discrimination case, the court upheld a $\$ 500$ compensatory damages award despite the defendant's claim that "there is no evidence that the plaintiffs suffered any loss or damages." "Id. But the Seventh Circuit's reasoning was perplexing: "[A]n award of compensatory damages under $\$ 1982$ or 'actual damages" under [42 U.S.C.] $\$ 3612$ [ $\$ 812$ of the Civil Rights Act of 1968, 82 Stat. 88] is appropriate for humiliation caused by the type of violations of rights established here. Humiliation can be inferred from the circumstances as well as established by the testimony." 491 F.2d at 636.

Many courts have also held that proven (including inferred) emotional distress and humiliation caused by racial discrimination are compensable elements of damage in cases in which some pecuniary loss was also shown. See, e.g., Gore v. 
These courts tread rather closely to the line of presuming damages, because the protected interest in such cases is basically the right to be treated with dignity, and the compensable "intangible" loss can be described as loss of dignity. Thus, it would appear that compensating for such intangible harm is virtually the same thing as compensating for the loss of the right in and of itself. The "proof" of intangible harm required, moreover, may amount to nothing more than an inference derived from the nature of the violation itself. 39

Despite the doctrinal proximity between this method of defining compensable injury and a presumption of substantial injury owing to the violation itself, the proof-of-mental-distress approach entails a procedure of evaluating the constitutional injury that poses distinct difficulties. The trier of fact supposedly assigns a dollar value to the intangible harm based on "proof," but, due to the very nature of emotional harm, this proof can be of only the most nebulous kind. ${ }^{40}$ When the plaintiff is required to prove his mental anguish by direct testimony, as is often the case, only a high-minded or disingenuous plaintiff will testify that he was emotionally indifferent to the infringement of his rights. ${ }^{41}$ Not only is self-serving testimony about the plaintiff's subjective reactions to the violation of dubious reliability and utility, but requiring constitutional tort damage awards to be based on such testimony also turns the process of enforcement of constitutional rights into a thespian contest to see who can make the most

Turner, 563 F.2d 159, 164 (5th Cir. 1977) (discrimination in apartment rentals); Hodge v. Seiler, 558 F.2d 284 (5th Cir. 1977) (discrimination in apartment rentals); Jeanty v. McKey \& Pogue, Inc., 496 F.2d 1119 (7th Cir. 1974) (discrimination in apartment rentals); Steele v. Title Realty Co., 478 F.2d 380, 384 (10th Cir. 1973) (discrimination in apartment rentals); Smith v. Sol Adler Realty Co., 436 F.2d 344, 351 (7th Cir. 1970) (discrimination in apartment rentals); Allen v. Gifford, 368 F. Supp. 317 (E.D. Va. 1973) (discrimination in housing sales); Gonzales v. Fairfax-Brewster School, Inc., 363 F. Supp. 1200 (E.D. Va. 1973) (discrimination in privately supported quasi-public schools), aff'd sub nom. McCrary v. Runyon, 515 F.2d 1082 (4th Cir. 1975), aff'd, 427 U.S. 160 (1976).

30 See Seaton v. Sky Realty Co., 491 F.2d at 637-38.

40 The sort of emotional harm referred to in the text is that compensable by general damages, and is often characterized as "distress," "humiliation," or "mental anguish." Mental or emotional damage that is sufficiently serious to require therapy or to lead to diminution of earning capacity is seldom involved in these cases. But see Allen v. Gifford, 368 F. Supp. 317 (E.D. Va. 1973) (racial discrimination found to have aggravated emotional illness). The pecuniary losses associated with such damage would of course be capable of relatively precise proof. On the subject of proof of intangible emotional harm, see Love, supra note 3 , at 1268-70.

41 Hodge v. Seiler, 558 F.2d 284, 288 ( 5 th Cir. 1977), a housing discrimination suit brought by a black husband and white wife, in which the wife was denied compensatory damages because she testified that she was not upset, is not a typical case. 
sympathetic impression on the jury. ${ }^{42}$ One might well question whether it is appropriate to offer substantially different amounts of compensation to persons deprived of the same constitutional right in a similar manner simply because one is a more demonstrative witness than the other.

Even in cases in which direct testimony is dispensed with, and the trier of fact is permitted to infer intangible injury from the nature of the violation, the jury's largely unreviewable award is likely to be determined primarily by the extent of its sympathy with the plaintiff, which in turn may depend on his wealth, social status, and personal appearance. The practical result may be that the slum dweller's interests in liberty and security are seriously undervalued relative to those of middle class plaintiffs. ${ }^{43}$

42 The same objection applies to cases tried by a judge. The vindicatory function of constitutional tort suits is impaired whenever judicial attention is diverted from the nature of the right violated to the emotional makeup of the individual plaintiff thus permitting awards to vary freely with the discretion and sympathy of the trier of fact. See note 43 infra for examples of the variations in awards from one constitutional case to the next.

43 Judge Newman, among others, has argued that middle-class juries habitually undervalue the rights of plaintiffs from poorer segments of the community. See Newman, supra note 4 , at 454,465 . Newman states flatly that "[w]hen jurors learn that a plaintiff has been in prison, as they frequently do when his credibility is attacked by prior convictions, it is not unusual for them to value a few days of his life in jail at a figure as low as $\$ 500 . " I d$. 465 . One student commentator extends this argument to the exercise of unpopular rights: "The antimajoritarian nature of constitutional guarantees further suggests that a jury reflecting community standards may not fairly value the unpopular exercise of constitutional rights." Harvard Note, supra note 8 , at 988-89.

- For commentary on the perils of facing an unsympathetic jury-for whatever reason-in constitutional tort cases, see Colley, Civil Actions for Damages Arising Out of Violations of Civil Rights, 17 Hastengs L.J. 189, 203-04 (1965) (judges and juries who are not members of minority groups "operate in a vacuum" when they attempt to call upon their own experiences to measure damages in civil rights cases); Note, Monetary Claims Under Section 1983: The Right to Trial by Jury, 8 HaRv. C.R.-C.L. L. REv. 613 (1973) (defendant's assertion of jury-trial right may frustrate purpose of $\$ 1983$ in cases in which unpopular causes face potentially hostile juries); Note, Developments in the Law-Employment Discrimination and Title VII of the Civil Rights Act of 1964, 84 Harv. L. Rev. 1109, 1264 n.371 (1971) (majority of jury demands in Title VII cases have come from southern defendants in cases in which racial discrimination was alleged).

The theory that juries may undervalue the constitutional rights of less-favored plaintiffs finds circumstantial support in the case law. Two unrelated cases together suggest graphically the plight of the unpopular plaintiff. In Fisher v. Volz, 496 F.2d 333 ( $3 \mathrm{~d}$ Cir. 1974), an award of $\$ 250$ in punitive damages and no compensatory damages for the occupants of each of several apartments invaded by the police without probable cause was upheld despite evidence that the police caused physical damage and exhibited flagrant disregard for the residents' rights. Yet, in Rhoads v. Horvat, 270 F. Supp. 307 (D. Colo. 1967), a $\$ 5000$ compensatory and $\$ 2500$ punitive damages award for arrest without probable cause and less than an hour's detention was allowed despite the absence of any allegations of physical abuse. The jury award had been even higher, but the trial judge ordered it reduced to $\$ 7500$ total. The plaintiffs in Fisher were black ghetto residents; the plaintiff in Rhoads was a college professor. 
Basista $v$. Weir, ${ }^{44}$ the widely cited Third Circuit case, ${ }^{45}$ illustrates a third approach to the problem of compensating constitutional tort victims who cannot prove pecuniary loss: allowing awards with both compensatory and punitive elements to pass entirely under a "punitive" label. Basista was a section $1983^{46}$ action in which the plaintiff claimed to have been beaten and illegally arrested by a policeman. Plaintiff's counsel stated at a pretrial conference that his client was not seeking any special damages but sought to recover for the deprivation of his constitutional rights. ${ }^{47}$ The jury, apparently confusing the concepts of "punitive" and "compensatory" damages, 48 awarded no compensatory and $\$ 1500$ punitive damages. The Third Circuit held that such an award was permissible-that nominal damages could be presumed from the deprivation of a right to which the plaintiff was entitled and that such damages were sufficient to support a punitive award. ${ }^{\mathbf{4 9}}$

Like the proof-of-mental-distress approach, the Basista court's doctrinal amendment, though designed to approximate the practical result of presuming damage, falls short in both theory and reality. The award in Basista must logically have contained a compensatory element, despite its label. In order to find for Basista on the merits, the jury had to believe at least some of his evidence regarding his illegal arrest and detention. If Basista's fourth amendment rights were really worth nothing, or only a nominal amount, in the jury's eyes-as would appear from its failure to award any compensatory damages-it is difficult to see why the jurors were moved to exact a $\$ 1500$ "punishment" from the defendant for violating them. Yet the Third Circuit's willingness to tolerate erosion of the compensatory/punitive distinction allowed it to avoid formulating adequate rules for compensatory awards in constitutional cases in which pecuniary loss cannot be shown.

44340 F.2d 74 ( 3 d Cir. 1965).

45 Basista has been cited by the Supreme Court, with apparent approval, in Carey v. Piphus, 435 U.S. at 264 n.22 (1978), and Adickes v. S. H. Kress \& Co., 398 U.S. 144, 233 (1970) (Brennan, J., concurring and dissenting). The lower federal courts have also frequently cited Basista. See, e.g., Paton v. La Prade, 524 F.2d 862, 872 (3d Cir. 1975); Seaton v. Sky Realty Co., Inc., 491 F.2d at 637; Fisher v. Volz, 496 F.2d 333, 346 (3d Cir. 1974); Donovan v. Reinbold, 433 F.2d 738, 743 (9th Cir. 1970); Tatum v. Morton, 386 F. Supp. 1308, 1313 (D.D.C. 1974); Washington v. Official Court Stenographer, 251 F. Supp. 945 (E.D. Pa. 1966).

4642 U.S.C.A. $\$ 1983$ (Supp. 1980). The full text of $\S 1983$ is provided at note 3 supra.

47 " I said there is no special damage except, well, compensatory or punitive but both for the same thing. It is a violation of the civil rights." "340 F.2d at 85 . 48 See text accompanying notes 19-25 supra.

49340 F.2d at $87-88$. 
Future Basista-like plaintiffs to whom punitive damages are not available, either because a defendant acted with insufficient bad faith, ${ }^{, 0}$ or because a defendant is a government agency immune from liability for punitive damages, ${ }^{61}$ would, under Basista, be entitled only to nominal damages for the violation of their constitutional rights. ${ }^{52}$ The Basista court quoted an 1896 opinion in support of its holding:

[T] here is neither sense nor reason in the proposition that [punitive] damages may be recovered by a plaintiff who is able to show that he has lost $\$ 10$, and may not be recovered by some other plaintiff who has sustained, it may be, far greater injury, but is unable to prove that he is poorer in pocket by the wrongdoing of defendant. ${ }^{53}$

Yet it is hardly more sensible that one's ability to recover substantial damages should depend entirely on either the subjective state of mind or statutory immunity from punitive damages of the defendant in a particular action.

\section{The Presumed Damages Approach}

Unlike the approaches discussed above, the doctrine of presumed damages directs the trier of fact's focus not to the subjective reactions of the individual plaintiff or to the degree of malice exhibited by the defendant, but to the nature of the right violated.

The doctrine of presumed damages requires the jury in a constitutional tort case to make three separate inquiries. Although these determinations are not "easy," the jury's task under a presumed damages instruction has the advantage of being logical in light of the policies of Bivens and section 1983 actions. ${ }^{54}$ First,

50 See note 19 supra \& accompanying text.

51 The Federal Tort Claims Act, for example, disallows punitive damage awards against the United States. 28 U.S.C. $\$ 2674$ (1976). See Love, supra note 4, at 1282.

Note that this is one situation in which $\$ 1983$ plaintiffs are treated differently than Bivens plaintiffs. Because the defendant in a Bivens action is statutorily immune from punitive damage awards, the Basista approach is of little relevance in that context. See generally note 2 supra.

62 The district court's decision in Halperin v. Kissinger, $434 \mathrm{~F}$. Supp. at 1195, is an illustration of this concept. Unwilling to hold that the defendants, all high government officials, had been "reckless, wanton or malicious," to recognize a presumption of damages, or to engage in speculation about emotional distress, the trial court restricted the Halperins to one dollar nominal damages. Halperin is discussed more fully below. See notes 91-107 infra \& accompanying text.

53 Basista v. Weir, 340 F.2d at 87-88 (quoting Press Pub. Co. v. Monroe, 73 F. 196, 201 (2d Cir.), appeal dismissed, 164 U.S. 105 (1896)).

54 See text following note 6 supra. 
even if the plaintiff has submitted no proof on the amount of injury he suffered, the jury should be permitted to compensate him for the violation of his constitutional right. The jury should determine, in the light of its common experience, what amount would be sufficient to compensate a citizen for the loss of the right in question. Second, the jury should consider, in determining the sum necessary to compensate for invasion of the right, whether the violation was of the sort that would cause a reasonable person to suffer such consequential injury as mental distress, embarrassment, and humiliation. Finally, the jury should determine whether the defendant should be punished for his conduct. If so, that punishment should be expressed only through an express award of punitive damages. In setting compensatory damages, in contrast, the defendant's conduct is relevant only to determining the magnitude of the deprivation to be compensated. For example, unreasonable wiretapping for six months is a greater constitutional violation than unreasonable wiretapping for six days and merits a higher compensatory award. In the context of the jury's compensatory award, however, a six day wiretap by a defendant who acted out of personal spite is a violation of the same magnitude as a six day wiretap by a defendant who merely acted unreasonably.

Despite the clear surface logic of the presumed damages solution to the problem of compensating for the deprivation of constitutional rights, the doctrine is hinged on the assumption, not yet discussed, that such rights can reasonably be assigned a dollar value. This Comment's next task is to examine the validity of such an assumption.

The Third Circuit's opinion in Hague v. Committee for Industrial Organization ${ }^{55}$ supports the view that first and fourth amendment rights may, at least in the abstract, be assigned a dollar value. Although the CIO, alleging violation of both first and fourth amendment rights, sought an injunction rather than damages, an issue was raised whether the amount-in-controversy minimum for federal jurisdiction was met..$^{58}$ The court held that the amount in controversy should be determined by the value of the rights of which plaintiffs alleged deprivation and that the trial judge's finding, that the jurisdictional requirement was met, could be taken as a finding that plaintiffs could have recovered such an amount in a

55101 F.2d 774 (3d Cir.), modified on other grounds, 307 U.S. 496 (1939).

56 Id. 789-80. The amount-in-controversy requirement in 1939 was only $\$ 3000$. See Act of March 3, 1911, ch. 231, $\$ 24,36$ Stat. 1091 (current version at 28 U.S.C. $\$ 1331$ (1976)), cited in Hague, 101 F.2d at 789. 
suit at law for deprivation of the same rights. ${ }^{57}$ Such a finding, moreover, need not be based on specific evidence of value, "but rather upon the trial judge's own knowledge and opinion as to the value." 58

The voting rights cases ${ }^{59}$ also support the notion that reasonable people can assign monetary values to intangible rights. According to this line of authority, "the amount of the damages is a question peculiarly appropriate for the determination of the jury, because each member of the jury has personal knowledge of the value of the right." 60

Thus, the underlying assumption of the presumed damages doctrine-that constitutional rights can rationally be assigned dollar values-has some validity. This Comment takes the additional step of arguing that it is primarily the jury's-as opposed to the judge's or Congress's-function, at least in the first instance, to set the value of constitutional rights in particular cases. ${ }^{81}$ Concededly, leaving the valuation of constitutional rights to jurors does present potential problems. But these problems are readily solvable through traditional mechanisms of judicial review.

67 Id.

58 Id. 790. Other constitutional tort cases recognize the inherent value of constitutional rights by finding that the "minimum amount" jurisdictional requirement is satisfied. See, e.g., Hartigh v. Latin, 485 F.2d 1068 (D.C. Cir. 1973) ( 1983 action against police officers for excessive use of force meets the $\$ 10,000$ threshold for federal jurisdiction), cert. denied, 415 U.S. 948 (1974); Sullivan v. Murphy, 478 F.2d 938, 960 (D.C. Cir.) (allegation of unlawful arrests at antiwar demonstrations sufficient to pass the $\$ 10,000$ federal jurisdiction requirement), cert. denied, 414 U.S. 880 (1973); Gomez v. Wilson, 477 F.2d 411, 420 (D.C. Cir. 1973) (complaint against police alleging constitutional violations need only be made in good faith, and the amount sued for is deemed to have been fixed in good faith as long as it is not "clear to a legal certainty" that no recovery could satisfy the jurisdictional minimum); Spock v. David, 469 F.2d 1047, 1051-52 (3d Cir. 1972) (first amendment rights, though difficult to value precisely, are capable of sustaining claims for damages in excess of the $\$ 10,000$ federal jurisdictional minimum).

59 Lane v. Wilson, 307 U.S. 268 (1939); Nixon v. Condon, 286 U.S. 73 (1932); Nixon v. Hermdon, 273 U.S. 536 (1927); Giles v. Harris, 189 U.S. 475 (1903); Wiley v. Sinkler, 179 U.S. 58 (1900); Wayne v. Venable, 260 F. 64 (8th Cir. 1919).

60 Wayne v. Venable, $260 \mathrm{~F}$. at 66.

61 Compare the approach of Judge Newman who advocates providing, in addition to compensatory damages for actual losses, "a liquidated damage sum to compensate for the value of the constitutional right denied." Newman, supra note 4, at 465 . He proposes either a constant amount or an amount to vary according to a schedule for different violations and different consequences. This proposal presumably would be accomplished by statute. Newman also suggests that juries not be informed that the liquidated damage figure would be added to its actual loss award, to prevent any temption to deflate its own assessment accordingly.

Other commentators have also offered proposals involving legislative action to implement some form of presumed damages. See Love, supra note 4, at 1282-85 (urging legislation to accomplish the goals of the presumed damages doctrine); Harvard Note, supra note 8 , at 988-90 (advocating legislative enactment of a fixed minimum recovery). 
Two 1977 District of Columbia Circuit cases involving police disruption of political demonstrations illustrate both the wide variations that can occur among evaluations of the same right by different triers of fact, and the capacity of judicial review to even out these discrepancies. In Tatum v. Morton ${ }^{62}$ the court of appeals held that it was error to limit a group of Quakers who were unlawfully arrested during a demonstration to $\$ 100$ each in damages, plus lost wages. Remanding for the trial court to set an award somewhere between that $\$ 100$ figure and the $\$ 10,000$ each plaintiff sought, Judge Levanthal's opinion stressed the need to compensate the demonstrators for the loss of their constitutionally protected freedom of speech. ${ }^{63}$ In Dellums v. Powell, ${ }^{64}$ on the other hand, the same circuit set aside as excessive an award of $\$ 7500$ to each of a group of demonstrators who were arrested in contravention of their first amendment rights, and to the congressman who was addressing them at the time of the arrests. Here, because the demonstration was virtually completed before any arrests were made, the court felt that the quantum of first amendment freedom lost was too small to support such a large award. ${ }^{65}$ The trial judge's instructions had not focused sufficiently on the relatively minimal nature of this infringement: "The jury cannot simply be set loose to work its discretion informed only by platitudes about priceless rights." 68

These cases may be read together to demonstrate that, although intangible constitutional rights can be assigned a monetary value, some system of review of such valuations is necessary to ensure that constitutional deprivations of similar character and magnitude are compensated in a similar fashion. Juries' judgments, based on the jurors' common experience of what a given right is worth, should be more susceptible of direct comparison than judgments about a given plaintiff's sensitivity to emotional distress, for example. Over time, therefore, conscious use of the presumed damages doctrine would permit trial judges and appellate courts to exercise more effectively the needed review of compensatory damage awards for the class of torts to which the presumption applies than could possibly be exercised under either of the alternative approaches discussed above. ${ }^{6 r}$

B2 562 F.2d 1279 (D.C. Cir. 1977).

63 Id. 1282.

64566 F.2d 167 (D.C. Cir. 1977), cert. denied, 438 U.S. 916 (1978).

65 Id. $195-96$.

66 Id.

67 See notes 37-53 supra \& accompanying text. 
Initially, the trial judge could guide the jury's damage award through his instructions to the jury. If, despite the instructions, the jury awarded the plaintiff a sum disproportionate to damages awarded by other juries for similar injuries, the judge could then exercise one of several remedial options available to him. Should the jury's verdict appear excessive, the judge could order a remittitur of the excess portion of the award ${ }^{88}$ or a new trial. In the case of an inadequate award, the judge does not have the comparable option of ordering an additur; ${ }^{69}$ rather, he is limited to ordering a new trial. The new trial option in either case may, however, be limited to the damages issue; the issue of liability need not be relitigated.70 Finally, traditional appellate review of either excessive or inadequate jury awards remains available. ${ }^{71}$

68 The doctrine of remittitur was examined critically by the Supreme Court in Dimick v. Schiedt, 293 U.S. 474 (1935). The Court suggested that it might not sanction the practice "if the question of remittitur were now before us for the first time." Id. 484. The Court noted, however, that "the doctrine has been accepted as the law for more than a hundred years and uniformly applied in the federal courts during that time." Id. 484-85. In light of this history, as well as the use of the practice in England before the adoption of the constitution, the Court concluded that "we may assume that in a case involving a remittitur . . . the doctrine would not be reconsidered or disturbed at this late day." Id. 485 . For a discussion of the history and the mechanics of the doctrine of remittitur, see generally $6 \mathrm{~A} \mathrm{~J}$. MOORE, MOORE's Federal Practice โ59.05[3] (1979); Carlin, Remittitur's and Additurs, 49 W. VA. L.Q. 1 (1942); Note, Remittitur Practice in the Federal Courts, 76 Colum. L. REv. 299 (1976).

69 The practice of additur was declared unconstitutional, as violative of the seventh amendment, in Dimick v. Schiedt, 293 U.S. 474 (1935). See generally 6A J. Moone, supra note 68, at $\llbracket 59.05[4]$. Since Dimick, additur has not been permitted in the federal courts, see, e.g., Miller v. Tennessee Gas Transmission Co., 220 F.2d 434 (5th Cir. 1955), at least when the right to a jury trial is founded on the seventh amendment, see generally United States v. Kennesaw Mountain Battlefield Ass'n, 99 F.2d 830 (5th Cir. 1938), cert. denied, 306 U.S. 646 (1939).

70 See $6 \mathrm{~A}$ J. Moore, supra note 68, at I 59.06 .

71 The Supreme Court has upheld statutes directing appellate review of capital punishment sentences to ensure that the circumstances of the case were similar to those in which the death penalty had been imposed in the past. Gregg v. Georgia, 428 U.S. 153 (1976); Proffitt v. Florida, 428 U.S. 242 (1976). These and related cases are discussed in The Supreme Court, 1975 Term, 90 HaRv. L. Rev. 56, 63-76 (1976).

Of course, the interest of a constitutional tort plaintiff in receiving a fair damage award is not of the same magnitude as a defendant's interest in not receiving the death penalty unfairly. But basic trial judge supervision coupled with appellate review should not require too great an expenditure of judicial resources. In fact, the more straightforward presumed damages approach should represent a move towards conservation of judicial resources when contrasted with the unprincipled, freewheeling review currently exercised. See notes 37-53 supra and notes 146-55 infra \& accompanying text.

The only possible judicial resource objection to this Comment's approach to the presumed damages inquiry is that too many new trials may result as a consequence of this system. Such an objection would have to rely on the assumption that many plaintiffs would refuse to accept remittiturs in the excessive verdict cases 
This sort of gentle guidance of jury discretion should not threaten any important values of the jury system. Juries will still express societal values in their assessments of the worth of various constitutional rights. Trial judges and appellate courts will merely ensure some degree of comparability between awards for similar violations through devices such as the remittitur and new-trial order, on the theory that a jury assessment grossly out of line with what other juries have assessed in similar circumstances would likely be based on some impermissible prejudice or misapprehension. The value of allowing a jury to weigh evidence is not strongly implicated here, because the presumption will come into play only in cases in which there is little or no competent evidence bearing on the damage issue. ${ }^{72}$ The presumption and special supervision and review would apply only to that aspect of the injury that is the same from case to case: the deprivation by a government agency or official of a citizen's right to free expression (as in a politically motivated firing case); a citizen's interest in liberty and personal security (as in an unreasonable arrest and detention case); or a citizen's interest in privacy (as in a wiretapping case).

and on the unavailability of the additur option in the undervaluation cases thus resulting in frequent new trial orders.

This argument must be rejected for three reasons. First, it is not at all clear that new trials will result from any significant portion of new trial orders by either trial judges or appellate courts. It appears reasonable to assume that most of those cases will settle prior to any retrial of the issues. The judge, or court ordering the new trial can even push the parties towards settlement by indicating what he thinks would be a fair award under the circumstances. See, e.g., Huntley v. Community School Bd., 579 F.2d 738 (2d Cir. 1978) (trial judge said that he would have awarded at least $\$ 1000$ for this violation of constitutional rights).

Second, to the extent that new trials do result, they need not be full-blown trials on the merits. Retrial of only the plaintiff's damage claims should not present too great a burden on valuable judicial resources. See 6A J. Moore, supra note 68 , at $\llbracket 59.06$.

Finally, this Comment takes the position that the vindication of constitutional rights is a sufficiently consequential societal interest that whatever increased burden on judicial resources results is more than offset by the benefits of implementing a presumed damages approach.

Thus, when contrasting the various proposals for legislative action discussed by other commentators, see note 61 supra, with this Comment's approach leaving the presumption of damages to trial judges, juries, and appellate courts, the advantage of the legislative approaches with respect to conservation of judicial resources is quite slight. And the legislative proposals do have one significant disadvantage. This Comment's alternative approach would preserve more tlexibility than legislatively decreed liquidated damages or a fixed minimum recovery. Juries would retain the power to tailor awards according to the magnitude of the violation (e.g., the length of the wiretap or illegal detention or the presence of mitigating or exacerbating circumstances). It would be relatively difficult to draft a statute taking such variations in magnitude into account. Also, juries could adjust the range of awards for changes in the cost of living as often as necessary, whereas a statute would have to be periodically amended.

72 Special damages, if any, could still be separately pleaded, proved, and awarded. 


\section{Presumed Damages in the Fourth Amendment Context}

Barring legislative action, the Supreme Court's decision in Carey v. Piphus ${ }^{73}$ forecloses the presumed damages option in the procedural due process context. But Piphus did leave open the possibility that the presumed damages concept might be appropriate to remedy violations of other constitutional rights. ${ }^{74}$ This section explores the impact of Piphus on fourth amendment cases involving purely intangible harm, focusing specifically on the wiretapping of Morton Halperin's home during the Nixon administration.

\section{A. Carey v. Piphus}

A close examination of Justice Powell's opinion in Piphus reveals that the Court's holding was based on the notion that procedural due process violations, in and of themselves, are not sufficiently likely to cause substantial intangible harm to justify relieving plaintiffs of their burden of proof on the issue. ${ }^{75}$ The Court's essential concern was with the differences it perceived between violations of procedural and violations of substantive constitutional rights.

Plaintiffs had contended that damages should be presumed to flow from their deprivation of procedural due process, analogizing their case to one of defamation. ${ }^{78}$ The Court agreed that presumed damages would be appropriate in a case of defamation, noting that defamation is likely to cause serious injury, both reputational and emotional. Injury to reputation, the Court stated, is often quite difficult to prove; furthermore, such injury, like emotional distress, is so likely to occur that "there arguably is little reason to require proof of [either] kind of injury." 77

The Court rejected the presumed damages approach in the procedural due process area, however, finding several crucial distinctions between deprivations of this nature and the defamation example. First, the Court stated that it was not reasonable to

73435 U.S. 247 (1978).

74 See notes 84-88 infra \& accompanying text. Following the decision in Piphus, the Fourth Circuit approved a presumed damages approach for a fourteenth amendment claim. Mickens v. Winston, 462 F. Supp. 910 (E.D. Va. 1978) (black prisoner protested segregated conditions in city jail), aff'd mem., 609 F.2d 508 (4th Cir. 1979). See notes 89 \& 90 infra \& accompanying text.

75 Carey v. Piphus, 435 U.S. 247 (1978). Indeed, the Court stated that "[p]rocedural due process rules are meant to protect persons not from the deprivation, but from the mistaken or unjustified deprivation of life, liberty, or property." Id. 259. 
presume that injury is as likely to occur from a deprivation of procedural due process as from the infringement upon one's rights that occurs in the case of defamation. ${ }^{78}$

Second, the Court felt that "where a deprivation [of a "protected interest' or substantive right] is justified but procedures are inadequate, whatever distress a person feels may be attributable to the justified deprivation rather than to deficiencies in procedure." 79 There would, then, be two possible causes of the plaintiff's distress: the procedural deprivation, which would be compensable upon proof of injury, and the justified deprivation of a substantive right, which, being justified, would not be compensable. ${ }^{80}$ This "ambiguity in causation," which does not occur in a defamation case, was felt to provide a strong reason for requiring the plaintiff to prove that his distress was actually caused by the procedural deficiency itself. 81

Finally, noting that "[d]istress is a personal injury familiar to the law," 82 the Court "fore[saw] no particular difficulty in producing evidence that mental and emotional distress actually was caused by the denial of procedural due process itself." 83

Far from expressing a broad rule that damage may not be presumed to flow from the violation of all constitutional rights, the Court in Piphus carefully limited its holding to the context of violations that are merely procedural. ${ }^{84}$ Rejecting the plaintiffs' reliance on racial discrimination, voting rights, and fourth amendment cases ${ }^{85}$ without expressing any opinion on the continuing vitality of the cases cited, Justice Powell stressed that "the elements and prerequisites for recovery of damages appropriate to compensate injuries caused by the deprivation of one constitutional right are not necessarily appropriate to compensate injuries caused by the

78 Id. 263.

Where the deprivation of a protected interest is substantively justified but procedures are deficient in some respect, there may well be those who suffer no distress over the procedural irregularities. Indeed, in contrast to the immediately distressing effect of a defamation per se, a person may not even know that procedures were deficient until he enlists the aid of counsel to challenge a perceived substantive deprivation.

Id. (emphasis in original).

79 Id.

$80 \mathrm{Id}$.

81 Id.

$82 I d$.

83 Id.

84 Id. 264-65.

$85 \mathrm{Id}$. 
deprivation of another." ${ }^{80}$ Moreover, Justice Powell stated that "the rules governing compensation for injuries caused by the deprivation of constitutional rights should be tailored to the interests protected by the particular right in question-just as the common-law rules of damages themselves were defined by the interests protected in the various branches of tort law." 87 Thus, under the governing principles of Piphus, the likelihood that substantial and difficult-to-prove harm will flow directly from or inhere in the invasion of a given constitutionally protected interest in most cases involving infringement of that particular right is the key to determining whether the victim of such an invasion should be relieved of the burden of proving harm. ${ }^{88}$

At least one court has already faithfully implemented the Piphus inquiry in the context of the fourteenth amendment. In Mickens v. Winston, ${ }^{89}$ the District Court for the Eastern District of Virginia reviewed the history and nature of the equal protection right and segregation and concluded that "[a]lthough plaintiff has failed to vocalize, with any specificity, his alleged injury, confining his testimony to 'feeling bad' by virtue of defendant's intentional policy of racial segregation, the Court concludes he was presumptively injured, for which he is entitled to a monetary award." 90

\section{B. Halperin v. Kissinger}

Halperin v. Kissinger ${ }^{91}$ squarely presented the question whether substantial damages should be presumed to flow from wiretapping in violation of the fourth amendment. ${ }^{.2}$ Morton Halperin,

86 Id.

87 Id. 259.

88 Thus, the Court was able to conclude as follows:

In sum, then, although mental and emotional distress caused by the denial of procedural due process itself is compensable under $\$ 1983$, we hold that neither the likelihood of such injury nor the difficulty of proving it is so great as to justify awarding compensatory damages without proof that such Id. 264.

injury actually was caused.

89462 F. Supp. 910 (E.D. Va. 1978), affd mem., 609 F.2d 508 (4th Cir. 1979). In Mickens, the plaintiff, a prisoner incarcerated in a segregated jail, was relieved of the burden of proving injury. The plaintiff's claim was grounded in the equal protection clause of the fourteenth amendment.

90 Id. 913.

91424 F. Supp. 838 (D.D.C. 1976) (liability); 434 F. Supp. 1193 (D.D.C. 1977 ) (damages), rev'd in part and remanded, 606 F.2d 1192 (D.C. Cir. 1979), cert. granted, $100 \mathrm{~S}$. Ct. 2915 (1980) (No. 79-880).

92 Only the constitutional damages issue in Halperin will be discussed in this Comment. The circuit court remanded the case for a determination of several additional factual issues. Constitutional remedies will apply only to the portion of 
an aide to former National Security Advisor Henry Kissinger, and his family sued Kissinger, former President Richard Nixon, former Attorney General John Mitchell, and other federal officials ${ }^{23}$ allegedly responsible for placing and maintaining a tap on the Halperins' home telephone for a twenty-one month period in 1969 through 1971. Although the ostensible purpose of the tap was to obtain information regarding leaks of national security information to the press, it never yielded any information on this subject. ${ }^{94}$ The Halperins claimed that the tap was maintained, even after an FBI recommendation that it be discontinued, ${ }^{95}$ because the White House found information about Halperin's private political activities useful. ${ }^{98}$ At no point did the defendants seek a court order for the surveillance,, 87 nor did they make any attempt to avoid eavesdropping on calls that were of a purely familial nature. ${ }^{98}$

Although the district court held that this surveillance violated the fourth amendment, ${ }^{99}$ the court concluded that the plaintiffs' failure to plead and prove "actual" damages precluded them from recovering more than one dollar in nominal damages. ${ }^{100}$ The court of appeals agreed that the fourth amendment's reasonableness requirement was likely violated by some portion of the wiretap ${ }^{101}$ but found it necessary to remand the case. In so doing, it instructed the lower court to allow plaintiffs to "show loss due to emotional distress and mental anguish .... Such harm might be demonstrated through direct testimony of the plaintiffs or might be 'inferred from the circumstances,' and if established would surely entitle the Halperins to more than nominal recovery." 102 Plaintiffs' failure to offer proof of such injury in the summary proceed-

the 21 month tap that the district court determines to have been in violation of the fourth amendment and not a violation of title III, supra note 10, which took effect in mid-tap.

93 The other defendants were presidential aides H. R. Haldeman, John Ehrlichman, Alexander Haig, and Jeb Magruder; FBI Director Clarence Kelly; FBI official William Sullivan; Assistant Attorney General Robert Mardian; and the Chesapeake and Potomac Telephone Company.

94606 F.2d at 1197-98.

95 Id. 1197-98.

28 Id. 1205.

97 Id. 1196-99.

98 Id. $1197-98$.

99 424 F. Supp. at 843. The District Court refused to apply title III, supro note 10, to any portion of the tap. 424 F. Supp. at 841-42. This holding was reversed by the court of appeals. 606 F.2d at 1205-06.

100434 F. Supp. at 1194-95.

101606 F.2d at 1206.

102 Id. 1208 (footnote omitted). 
ings below was attributed to a "pre-Piphus belief that injury should be presumed." 103

Judge Wright's opinion for the court of appeals recognized that Carey v. Piphus ought not to control the damage issue in Halperin, ${ }^{104}$ because "[t]he substantive rights asserted by the Halperins are of a much different character" from the procedural due process rights involved in Piphus. ${ }^{105}$ But the court apparently concluded that allowing the Halperins to "prove" injury under a liberal standard ${ }^{106}$ would be an equally effective, and less controversial, method of compensating the plaintiff in this case than would open approval of the presumed damages concept. Of course, the circuit court failed to acknowledge both the practical difficulties and logical deficiencies that inhere in such a damages theory. ${ }^{107}$

\section{Damages for Unreasonable Wiretapping After Piphus}

Tested by Piphus's standards, the unconstitutional invasion of the Halperins' privacy was a deprivation for which a presumption of injury is appropriate. The right involved in Halperin-the fourth amendment guarantee against unreasonable searches and seizures-is a substantive one not posing the difficulties in causation perceived by the Piphus Court. Further, because the common law permitted the use of the doctrine of presumed damages in analogous invasion-of-privacy cases, Piphus's instruction to examine common law analogues provides additional support for any decision to presume damages in the fourth amendment area.

\section{The Substance/Procedure Distinction}

The motivating force behind the enactment of the fourth amendment was the desire to secure the citizens' substantive right

103 Id. 1207 n.103.

104 Note that, though Halperin was a Bivens action, the District of Columbia Circuit did not attempt to distinguish Piphus as a $\$ 1983$ proceeding. Presumably, this was a direct result of the near identity between the elements and standards applicable to both $\$ 1983$ and Bivens actions. See note 2 supra. In fact, the Piphus Court relied on Bivens itself, at least in part, to establish that the compensation of injuries is one of the purposes of $\$ 1983$. See Carey v. Piphus, 435 U.S. at 255. See generally Harvard Note, supra note 8 , at 973-74.

105606 F.2d at 1207 n.100.

106 In an apparent effort to ensure that the Halperins receive a generous opportunity to prove injury, the court noted that "in cases involving constitutional rights, compensation should not be approached in a niggardly spirit. It is in the public interest that there be a reasonably spacious approach to a fair compensatory award for denial or curtailment of the right v. Morton, 562 F.2d 1279, 1282 (D.C. Cir. 1977)).

107 See text accompanying notes 37-53 supra. 
to security from unwarranted intrusions into privacy by the government. ${ }^{108}$ As the court of appeals in Halperin stated:

Although the technology of investigation has developed dramatically in the last century, the dangers of unwarranted governmental intrusion into citizens' private lives have not changed since Justice Bradley wrote in Boyd $\boldsymbol{v}$. United States:

It is not the breaking of [a man's] doors, and the rummaging of his drawers, that constitutes the essence of the offence; but it is the invasion of his indefeasible right of personal security, personal liberty and private property $* * *$ ***

Without vigilant protection of a private space in which each citizen is free to pursue his own ideas and aspirations, we would betray our vision of a society based on the dignity of the individual. ${ }^{109}$

It is this substantive guaranty of privacy that provides the basis of the Halperins' cause of action. That this privacy is highly valued by the American people is implicit in the Constitution.110 It is reasonable to assume that injury will result from a violation of this privacy, just as injury may be presumed to flow from defamation. ${ }^{111}$ There is no "ambiguity of causation" 112 problem present; any distress the Halperins felt was quite clearly caused by the actual invasion of their privacy, and not by any underlying "justified deprivation." 113 While it might not be impossible to prove some

108 See notes 123-31 infra \& accompanying text.

109606 F.2d at 1199-1200 (quoting Boyd v. United States, 116 U.S. 616, 630 (1886) (footnote omitted)).

110 See Griswold v. Connecticut, 381 U.S. 479, 484-86 (1965).

111 See notes 77 \& 78 supra \& accompanying text.

112 Carey v. Piphus, 435 U.S. at 263.

113 Id. See text accompanying notes 79-81 supra. It is true that in some cases a reasonable governmental intrusion on privacy will violate the fourth amendment only because of a failure to obtain a prior judicial warrant. For example, in United States v. United States Dist. Ct., 407 U.S. 297 (1972), the Court stated:

It may well be that, in the instant case, the Government's surveillance of Plamondon's conversations was a reasonable one which readily would have gained prior judicial approval. But this Court "has never sustained a search upon the sole ground that officers reasonably expected to find evidence of a particular crime and voluntarily confined their activities to the least intrusive means consistent with that end." . . . The Fourth Amendment contemplates a prior judicial judgment, not the risk that executive discretion may be reasonably exercised.

Id. 317 (footnote and citation omitted).

In such cases, the logic of Piphus might arguably require the target of the search to prove that he suffered some intangible or tangible harm proximately 
emotional distress from the invasion of privacy, ${ }^{114}$ the Halperins' outrage at discovering that they had been wiretapped is so likely that forcing them to introduce evidence on the matter would be superfluous, as is proof of emotional distress in defamation actions. ${ }^{115}$ Further, use of the presumed damages concept is particularly appropriate in an invasion-of-privacy case, because otherwise the process of proof would compound the Halperins' injury by forcing them to disclose in court the nature and content of the private conversations that the government unlawfully overheard.

\section{Common Law Analogues}

The Piphus Court suggested that, when a constitutional violation has a close analogue in the common law of torts, courts should inform their judgment on the rules necessary to remedy the constitutional wrong by looking to the common law response to the analogous problem. ${ }^{116}$ Because the Halperins' fourth amendment claim is closely related to the common law tort of invasion of privacy, the acceptance of the presumed damages doctrine in that context supports the extension of the presumption to certain modern fourth amendment claims, including the Halperins', under the reasoning of Piphus.

The Restatement (Second) of Torts defines "intrusion upon seclusion," one of four distinct types of invasion of privacy, as intentional intrusion, physical or otherwise, "upon the solitude or seclusion of another or his private affairs, ... if the intrusion would be highly offensive to a reasonable person." 117 Wiretapping falls under this type of invasion of privacy. ${ }^{118}$ Proof of invasion of privacy alone entitled a plaintiff to recover damages for the

caused by the lack of a warrant rather than by the search itself in order to recover more than nominal damages. See notes 78-83 supra \& accompanying text. In Halperin, however, the failure to obtain a warrant cannot be seen as a merely procedural defect because the surveillance was specifically found to have been unreasonable, a "dragnet which lacked temporal and spatial limitation." 424 F. Supp. at 843. And, of course, an official warrant can never legitimate an unreasonable search and seizure. See generally Boyd v. United States, 116 U.S. 616 (1886) (holding that the fourth amendment incorporates the English common law condemnation of general warrants); notes 123-31 infra \& accompanying text (discussing the general warrant cases' holdings that a warrant cannot legitimate an unreasonable search or seizure).

114 See note 122 infra.

115 See Carey v. Piphus, 435 U.S. at 262; text accompanying note 77 supra. 116435 U.S. at 257-58.

117 Restatement (SEcond) of Torts \$652B (1977).

118 Id. Comment $\mathrm{b}$, illustration 3. 
presumed "harm to his interest in privacy resulting from the invasion." 119

Professor Dobbs states expressly that phone tapping would be a dignitary tort at common law. ${ }^{120}$ In the dignitary tort class of cases, "damages are 'presumed,' or the wrong is said to be damage in and of itself." 121 Thus, in a common law action on a tort such as wiretapping, the plaintiff's damage recovery would not "require proof of emotional harm to the plaintiff." 122

The well-known series of English cases from the 1760's establishing the illegality of general warrants ${ }^{123}$ also provides an interesting, if imperfect, analogue to the Halperins' situation. In each of these cases, substantial damages were awarded to the victims of searches and arrests executed under authority of the invalid warrants, even though the searches caused no physical damage and the arrestees were detained for only short periods.124 In Entick $v$. Carrington, ${ }^{125}$ for example, the jury awarded $£ 300$ damages against the warrant's executors for trespassing into the plaintiff's home by means of an unlocked door, interfering with his right to possession for four hours, and reading and taking away some of his private papers. ${ }^{128}$ In Huckle $v$. Money, ${ }^{127}$ the same sum was awarded to a

119 Id. $\$ 652 \mathrm{H}$.

$120 \mathrm{D}$. DosBs, supra note 15 , at $\$ 7.3$, at 530 . Other dignitary torts at common law would include assault, battery, false imprisonment, malicious prosecution, intentional infliction of emotional distress, alienation of affections, interference with voting and other electoral rights, and other invasions of privacy. Id. $\$ 7.3$, at 528-29.

121 Id. $\$ 7.3$, at 528 .

122 Id. $\$ 7.3$, at 529. Professor Dobbs goes on to explain:

On the other hand, emotional distress is a strong element in the dignitary tort cases and accounts for a substantial portion of the damages award.

Indeed in some of the cases, the tort looks very much like a special version of inflicting emotional distress. This is true in some cases of privacy invasion, as when the plaintiff is harassed, or shadowed, or his phone is tapped.

Id. $\$ 7.3$, at 530 (footnote omitted).

123 Entick v. Carrington, 95 Eng. Rep. 807 (K.B. 1765) ( $\& 300$ award for breaking into plaintiff's home and searching for papers); Beardmore v. Carrington, 95 Eng. Rep. 790 (K.B. 1764) ( 21000 award for breaking into plaintiff's home, seizing books and papers, and imprisoning plaintiff for six days); Huckle v. Money, 95 Eng. Rep. 768 (K.B. 1763) ( $\$ 300$ award for six hours imprisonment and seizure of papers); Wilkes v. Wood, 98 Eng. Rep. 489 (K.B. 1763) ( $\$ 1000$ award for breaking into plaintiff's home and seizing papers). See also Redshaw v. Brook, 95 Eng. Rep. 887 (K.B. 1769) ( 2200 award for entering home without a warrant and searching for twenty minutes).

124 The damages awarded ranged from $\& 200$ to $\& 1000$. See note 107 stupra. 12595 Eng. Rep. 807 (K.B. 1765).

128 Id. 807.

12795 Eng. Rep. 768 (K.B. 1763). 
journeyman printer detained for six hours under a general warrant, although the defendants "used him very civilly by treating him with beef-steaks and beer, so that he suffered very little or no damages." 128 The Lord Chief Justice, upholding this award against an excessiveness attack, stated:

[T] he personal injury done to him was very small, so that if the jury had been confined by their oath to consider the mere personal injury only, perhaps 20 [pounds] damages would have been thought damages sufficient; but the small injury done to the plaintiff, or the inconsiderableness of his station and rank in life did not appear to the jury in that striking light in which the great point of law touching the liberty of the subject appeared to them at the trial .... [I] t was a most daring public attack made upon the liberty of the subject. ${ }^{129}$

The awards in these cases undoubtedly contained a punitive element, ${ }^{130}$ which the English juries were not required to label separately. ${ }^{131}$ But they nevertheless illustrate the zealous protection at common law of intangible interests in liberty and security, a goal accomplished by awarding substantial damages for the infringement of such interests, even in the absence of physical or economic harm or evidence of unusual emotional distress.

\section{Lower Court Use of the Presumed Damages Doctrine}

Further support for this Comment's thesis, that the presumed damages doctrine is an appropriate remedial tool in the fourth amendment context, can be found in the number of lower court

$128 \mathrm{Id} .768$.

129 Id. 768-69.

130 The cases may not be fairly dismissed as involving only punishment, however. The cases stressed three ideas: the high inherent value of the rights violated; the need to deter similar conduct in the future; and the need to punish the perpetrators of the tortious searches and seizures. For example, in Wilkes, the Lord Chief Justice stated that

a jury have it in their power to give damages for more than the injury received. Damages are designed not only as a satisfaction to the injured person, but likewise as a punishment to the guilty, to deter from any such proceeding in the future, and as a proof of the detestation of the jury to the action itself.

98 Eng. Rep. at 498-99. Only the criterion of "punishment to the guilty" is, according to American notions of the line between punitive and compensatory damages, purely a "punitive" concept. See notes 16-21 supra \& accompanying text.

131 See note 22 supra \& accompanying text. One commentator suggests that "exemplary damages" are viewed in England not as punishment, but as compensation for injured feelings and outrage. C. MaCormars, supra note 22 , at $\S 78$, at 279 . 
cases recognizing that compensation for deprivation of civil rights is a permissible element of a general damage award, even when there is evidence of other sorts of injury. ${ }^{132}$ Although the plaintiffs in many of these cases proved special damages, such as lost wages and medical expenses, or such relatively "concrete" types of general damage as pain from physical abuse and incarceration, an undefined portion of the total award is often attributed to the invasion of civil rights itself. ${ }^{133}$

Three unlawful arrest cases from district courts in New York, Texas, and Colorado are typical of this line of cases. In Manfredonia $v$. Barry, ${ }^{134}$ the plaintiffs were awarded $\$ 3500$ compensatory and $\$ 500$ punitive damages for the unlawful arrest itself, one night's detention, and the notoriety resulting from the episode. Although no physical or pecuniary loss was alleged, the court cited Wayne v. Venable, ${ }^{135}$ the famous case applying the presumed damages doctrine to voting rights violations, for the proposition that deprivation of a constitutional right by a government official is itself sufficient ground for the recovery of substantial compensatory damages. ${ }^{138}$ In Sexton $v$. Gibbs, ${ }^{137}$ the plaintiff neither claimed nor submitted proof of actual damage caused by his illegal arrest and the illegal search of his car. Nevertheless, the court noted that the "plaintiff suffered humiliation, embarrassment and discomfort in addition to being deprived of his federally protected rights," 138 and awarded a total of $\$ 750$ in damages. Finally, in Rhoads $v$. Horvat, ${ }^{139}$ evidence that the plaintiff was outraged by his arrest and brief detention, that he was afraid he would be unable to keep a date that evening, and that he was upset when his teaching colleagues jokingly referred to him as a "jailbird," was found sufficient to support an award of $\$ 5000$ compensatory and $\$ 2500$ exemplary damages. ${ }^{140}$ Again, the court cited Wayne $v$. Venable for the prop-

132 Although most lower federal court cases that have presumed damages were decided prior to the Supreme Court's decision in Piphus, the logic of their analyses remains valid. See notes $142-45$ infra \& accompanying text.

133 See, e.g., Rue v. Snyder, 249 F. Supp. 740 (E.D. Tenn. 1966) (\$650 award for false arrest with no physical injury, only $\$ 96$ actual loss); Brooks v. Moss, 242 F. Supp. 531 (W.D.S.C. 1965) ( $\$ 3500$ compensatory award for police assault includes element for "deprivation of rights as a citizen"); notes 134-41 infra \& accompanying text.

134401 F. Supp. 762 (E.D.N.Y. 1975).

135260 F. 64 (8th Cir. 1919). See notes 29 \& 32 supra \& accompanying text. 136401 F. Supp. at 770.

137327 F. Supp. 134 (N.D. Tex. 1970), aff'd, 446 F.2d 904 (5th Cir. 1971), cert. denied, 404 U.S. 1062 (1972).

138 Id. 143.

139270 F. Supp. 307 (D. Colo. 1967).

140 Id. 309-11. 
osition that the amount of general damages for the invasion of a civil right was up to the jury. ${ }^{141}$

To be sure, all of the cases cited and discussed above were decided prior to the Supreme Court's opinion in Carey v. Piphus. But the logic underlying the decisions in those cases-that violations of civil rights are compensable even without proof of actual losssurvives the Supreme Court's Piphus decision. The Court in Piphus carefully and expressly limited its holding to the violation of constitutional rights that are merely procedural. ${ }^{142}$ The Court even cited the aforementioned lower court cases, ${ }^{143}$ discussed them, ${ }^{144}$ distinguished them from the situation then confronting it, and found them not "controlling." 145

Even so, with few exceptions, ${ }^{146}$ the lower courts have generally appeared extremely hesitant, since the Piphus decision, to employ the doctrine of presumed damages, even in cases in which violations of a substantive constitutional right have occurred. This reluctance, which often occurs despite the lower court's express recognition that Piphus ought not to be controlling, has resulted in some rather strained efforts on the part of the courts to compensate plaintiffs for deprivations of substantive constitutional rights without presuming damages. ${ }^{147}$

141 Id. 309.

142435 U.S. at 262-65. See text accompanying note 84 supra.

143435 U.S. at $264-65$ n.22.

144 Id. 264-65 \& n.22.

145 Id. 265.

146 See Bryant v. McGinnis, 463 F. Supp. 373, 388 (W.D.N.Y. 1978) ( $\$ 1983$ case by prisoners asserting first amendment rights; court cited an unusual string of cases, including Piphts, in support of the proposition that substantial nonpunitive damages can be awarded under $\$ 1983$ for violations of constitutional rights involving "deprivation of intangible rights for which no pecuniary loss can be shown"; awarded $\$ 3000$ in compensatory damages to each plaintiff); Mickens v. Winston, 462 F. Supp. 910 (E.D. Va. 1978), aff'd mem., 609 F.2d 508 (4th Cir. 1979) (see notes 89 \& 90 supra \& accompanying text).

147 See, e.g., Williams v. Board of Regents of the Univ. Sys., No. 77-2305 (5th Cir. June 5, 1980) (first amendment firing case; jury awarded $\$ 20,750$ compensatory, $\$ 28,000$ punitive, and two cents nominal damages; compensatory award upheld for "doubt and resulting anguish" during the campaign despite plaintiff's subsequent victory in the election); Konczak v. Tyrrell, 603 F.2d 13 (7th Cir. 1979) (unlawful arrest and search case; jury awarded husband and wife a total of $\$ 12,500$ compensatory and $\$ 23,500$ punitive damages on proof of only $\$ 576$ in lost wages; court of appeals upheld compensatory award under Piphus, because the rights involved in this case were substantive and because the difference between the jury award, and the proof of actual damages was explained by "mental distress, humiliation, loss of reputation, and other general pain and suffering"), cert. denied, 100 S. Ct. 668 (1980); Baskin v. Parker, 602 F.2d 1205 (5th Cir. 1979) ( $\$ 1983$ suit to vindicate fourth amendment rights violated in an unreasonable and destructive search; trial judge awarded $\$ 263.85$ compensatory and $\$ 200$ punitive damages; court of appeals distinguished Piphus but still reversed and remanded "the case for the award of damages for humiliation and emotional dis- 
A recent case under the Federal Tort Claims Act, Birnbaum v. United States, ${ }^{148}$ provides an excellent example of the circuitous routes to which courts have needlessly turned to avoid presuming damages. The plaintiffs in Birnbaum sued for the invasion of their privacy resulting from an illegal CIA practice of opening and reading mail to and from the Soviet Union. ${ }^{149}$ Although each plaintiff had had only one letter intercepted, the federal district judge, in a pre-Piphus decision, awarded damages of $\$ 1000$ to each, holding that lack of any objective harm did not bar recovery..$^{150}$ The judge stated clearly that "[t]he law generally recognizes that where a person suffers an invasion of the right to privacy, awards are appropriate for general damages covering the injury of invasion itself, as well as for the resulting mental distress." 161

The Second Circuit, in a post-Piphus opinion, affirmed the district court award.152 But, citing Piphus, the circuit court transformed the damage issue into a question whether the plaintiffs' testimony supported a finding of $\$ 1000$ worth of "mental anguish." 153 The circuit court's analysis tended to show that the plaintiffs did not suffer any mental anguish, but then the court was moved to "interpret" a finding of the trial judge "generously" to mean that plaintiffs did in fact suffer sufficient mental anguish to support the damage award. ${ }^{154}$

The point that Birnbaum and the other post-Piphus cases demonstrate is quite clear: the broad language of the Supreme Court in Piphus has, for inexplicable reasons, pushed lower federal courts towards more and more convoluted and unprincipled maneuvers in their attempts to compensate deprivations of substantive constitutional rights. Because Piphus is so easily distinguishable, ${ }^{155}$

tress"); Reyes v. Edmunds, 472 F. Supp. 1218, 1229 (D. Minn. 1979) (warrantless search case; court held plaintiffs entitled to nominal damages for "damage inherent in this wrongful act" but did not discuss the possibility of presuming substantial compensatory damages); Shuman v. Standard Oil Co., 453 F. Supp. 1150 (N.D. Cal. 1978) (action under Equal Credit Opportunity Act by woman discriminatorily denied credit; court "follows" Piphus and held that damage will not be presumed to flow from acts of invidious discrimination; plaintiff was allowed to prove "actual damage" in the form of "embarrassment, humiliation and mental distress").

143436 F. Supp. 967 (E.D.N.Y. 1977), affd as modified, 588 F.2d 319 (2d

Cir. 1978).

149 Id. $971-72$.

150 Id. $987,990$.

151 Id. 987.

$152588 \mathrm{~F} .2 \mathrm{~d}$ at 335 .

153 Id. 333.

154 Id. 333-35.

165 See text accompanying notes 108-31 supra. 
however, these decisions say more about judicial reluctance to properly distinguish Piphus than they do about the continuing logic of the pre-Piphus cases.

\section{CONCLUSION}

The Supreme Court's ruling in Piphus should not be extended to preclude awards of presumed damages in unreasonable-searchand-seizure suits based on the fourth amendment. As the preceding discussion of Halperin illustrates, the rationale of Piphus does not apply to such cases, in which the constitutionally protected interest is the substantive right to privacy. Whereas the procedural rights involved in Piphus are, under the federal constitutional scheme, merely a mechanical means of guarding against wrongful or mistaken deprivations of other constitutional rights, the right to be free of unreasonable governmental intrusions into one's privacy is a highly prized substantive interest.

Thus, substantial injury can be said to flow directly from, or to inhere in, deprivations of this particular constitutional right. Moreover, acceptance of the presumed damages concept in the context of the common law tort of invasion of privacy supports application of the doctrine to the analogous constitutional tort. These distinctions may well have been contemplated by the Court when it limited the Piphus holding to procedural due process claims. In any case, nothing in the Piphus Court's opinion compels lower courts to resort to fruitless speculation about the quantum of emotional distress suffered by an individual plaintiff in order to compensate that plaintiff for an invasion of his fourth amendment right to privacy.

On the subject of compensation for the infringement of intangible constitutional rights, Mark Yudof has written: "The fact that the precise degree of injury may be difficult to calculate should not lead a court to award no damages; rather it should estimate damages, however crudely. Otherwise, the whole notion of an entitlement to dignity becomes a farce." 156 The presumed damages doctrine offers the best tool available for performing this estimation of the value of "dignitary" constitutional entitlements, such as the privacy protected by the fourth amendment. Combined with a judicial commitment to guiding and overseeing jury awards to ensure comparability, the doctrine should make constitutional tort suits a more consistent and rational means of vindicating society's most important civil rights.

156 Yudof, Liability for Constitutional Torts and the Risk-Averse Public School Official, 49 S. CaL. L. Rev. 1322, 1378 (1976). 